\title{
A New Design of DC/DC Converter to Improve the Efficiency of Photovoltaic System
}

\author{
Trung Hieu Trinh
}

\begin{abstract}
In a photovoltaic system, its power output is heavily reliant to the irradiance instantaneously and this make the efficiency of DC/DC converter using in the photovoltaic system reduces, especially during low irradiance period. This paper proposes a new DC/DC converter to improve the efficiency of a PV system. The main idea of the new DC/DC converter is developed a DC/DC converter with variable capacity to meet the variation in the output power of the photovoltaic system. The designed converter is combined from multi-small DC/DC converters to obtain a high enough capacity and these small DC/DC converters are able to switch on/off to change the percentage of power flowing through such as the power loss in small DC/DC converter is reduced. This designed converter is verified via experiment shoots. The results indicate that the efficiency of proposed converter is higher than that with a conventional DC/DC converter.
\end{abstract}

Index Terms - Design, DC/DC converter, efficiency, photovoltaic.

\section{INTRODUCTION}

Solar energy has been exploited in many countries in the word and it contributes a significant role in meet the high demand in many countries. According to the report of REN21 (Renewable Energy Policy Network for the 21 century), the capacity of solar installed in 2017 is $98 \mathrm{GW}$, increase in $30 \%$ comparing to $78 \mathrm{GW}$ in 2016 and it boosts the solar photovoltaic (PV) global capacity from 303GW in 2016 to $402 \mathrm{GW}$ at the end of 2017 [1]. It means the solar energy is developing in the word. It depends on the potential of solar energy (irradiation), investment, and objective, the scale and configuration of PV system can be different. In general, a PV project is from several Watt to several hundred mega Watt and components in a PV system may be not the same.

Generally, a PV system includes PV panels, battery, and converters [2]. The kind of converter using in the PV system depends on load, voltage level and so on. Normally, two configurations of PV system used popularly in the word is single-stage and two-stage [3]. For two-stage configuration, a DC/DC converter is used to boost the DC voltage output of PV panel to a higher voltage which is corresponding to the connected AC grid. However, the use of DC/DC converter increases the power loss in the PV system [4]. It means it reduces the efficiency of PV system. To save electric energy, it is important to increase the efficiency of the DC/DC converter. Practically, the power loss in DC/DC converters depends on its power flow [5]. Normally, the efficiency of DC/DC converter is optimum when the power transferring through is around $50 \%-60 \%$ of its rated value and it rapidly

Trung Hieu Trinh, Electrical Engineering Department, The University of Danang-University of Science and Technology, Danang city, Vietnam, Phone/ Mobile No.: +84947058220,

This work was supported by The University of Danang, code number project: B2016-ĐN02-08. reduces if the power percentage transferring through is below $40 \%$ [5]. However, for PV system, its power output is not constant. The PV system normally generates maximum power at noon and this data gradually reduces to the morning or the late afternoon [6], the time interval of low output power is quite long. In some case of shadow phenomenon, its output power is reduced to below $40 \%$ of rated value. In these cases, the efficiency of DC/DC converter is gradually decreased; it means power loss in DC/DC converter increases. Hence, it is necessary to propose a DC/DC converter with a high efficiency for PV system.

The structure of some DC/DC converter with high efficiency is proposed [7], [8]. The idea from this reference is to improve power loss in DC/DC converter in general and hence, its efficiency is improved. However, its efficiency still depends on power flowing. It means during the low power output of PV system, the efficiency of DC/DC converter is improved but it is still very low due to low power flowing. Hence, designing a DC/DC converter with variable capacity depending on the power output of PV system is necessary.

This paper designs a new DC/DC converter implemented in PV systems for electric energy saving purpose. The basic of the proposed DC/DC converter is able to variable its rating capacity corresponding to the output power variation of PV system. To obtain this purpose, the proposed converter, multi-DC/DC converter, consists of several small DC/DC converters to obtain a high enough capacity. The connection of these small DC/DC converters must be designed such that some of small DC/DC converters can be inserted to/isolated from the multi-DC/DC converter system. This proposed multi DC/DC converter is evaluated via experiment shoots. The results indicate that the efficiency of the multi-DC/DC converter is higher than that with a conventional DC/DC converter.

\section{DC/DC CONVERTER'S EFFICIENCY}

Generally, a DC/DC converter in a PV system is shown in Fig.1a. The main objective of DC/DC converter is to boost voltage from $V_{\mathrm{dc}_{-} \mathrm{i}}$ to $\mathrm{V}_{\mathrm{dc}_{-} \mathrm{o}}$ which is fixed to the $\mathrm{AC}$ voltage of the grid connected. The main components of DC/DC converter are Diodes, electronic switches like Thyristor, IGBT, Mosfet... In operation, to boost input voltage to a higher value, these switches must be switched on/off according to pulse supplying by controller. Depending on the input voltage and other requirements, the duty ratio of pulse supplying to these switches can be changed. In electronic devices, there is resistance which consumes a part of power flowing. Moreover, the turning on/off of electronic switches causes power loss. It means in operation, it exists power losses in the DC/DC converter [9]. We suppose that its power loss in total is $\Delta \mathrm{P}_{\text {loss }}$. According to [9], this power loss depends on power flowing through it. The efficiency of DC/DC converter is defined [9] 


$$
\eta=\frac{P_{o}}{P_{i}}=\frac{P_{i}-\Delta P_{\text {loss }}}{P_{i}}=1-\frac{\Delta P_{\text {loss }}}{P_{i}}
$$

where, $P_{i}, P_{o}$ are the power input and output of the DC/DC converter, respectively. Normally, this efficiency versus power flowing through is described as Fig. $1 \mathrm{~b}$.

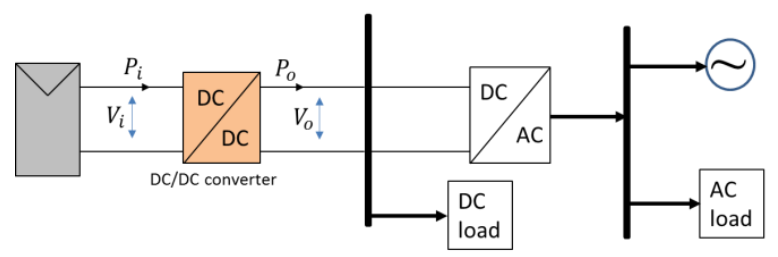

(a)

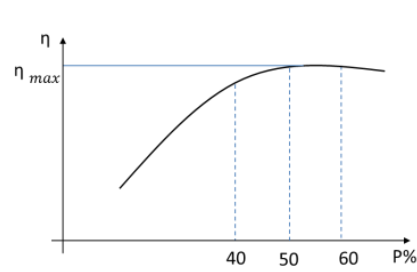

(b)

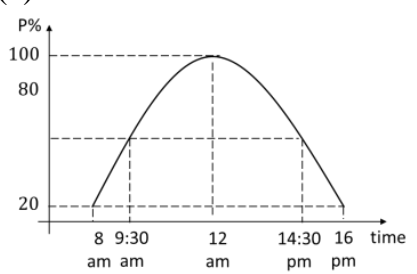

(c)
Fig.1. (a) DC/DC converter in PV system, (b) a sample efficiency curve of DC/DC converter, (c) a sample of power curve of a PV.

In the case of the DC/DC converter installed in a PV system as Fig.1 and normally, the power output of the PV is shown in Fig.1c which get maximum at 12am and minimum at the sunset and the sun rise. It means the percentage of power flowing through DC/DC converter can be below $50 \%$ before 9:30am and after 14:30pm and hence, the efficiency of DC/DC converter can be very low during these periods.

\section{DESIGN A NEW DC/DC CONVERTER}

From above analysis, to improve the efficiency of the DC/DC converter, we need to design a new DC/DC converter The new DC/DC converter in this paper does not focus on reducing power loss but we design a DC/DC converter with variable capacity. The idea is developed based on a multi DC/DC converter which consists of $n$ small DC/DC converters in parallel connection in the input side and serial connection in the output side, as shown in Fig.2a. The detail connection of the multi-DC/DC converter is shown in Fig.2b. Each small DC/DC converter is an isolated converter which is structured from 4 Mosfets, 4 diodes and a transformer as Fig 2.c. We suppose that the capacity of each small DC/DC converter is $P_{\text {rated_s. }}$. Hence, the rating of multi-DC/DC converter with $\mathrm{n}$ small DC/DC converters is

$$
P_{\text {rated_m(n) }}=n P_{\text {rated_s }}
$$

When the power output of the PV system is rated power $P_{p v_{-} \text {rating }}$, power flowing through a small DC/DC converter is

$$
P_{\text {norm_s }}=\frac{P_{\text {pv_rating }}}{n}
$$

To operate this multi-DC/DC converter in variable capacity, at the $\mathrm{i}^{\text {th }}$ small DC/DC converter, two electronic switches $\left(S_{i}^{i}, S_{0}^{i}\right)$ are installed at both sides of each small DC/DC converter as Fig.2b such that it can isolated it from the multi-DC/DC converter by switching off $S_{i}^{i}$ and switching on $S_{0}^{i}$. In the low irradiation period, we suppose that the output power of PV system $P_{p v}$ is below the rated power of PV system, $P_{p v}=0.4 P_{p v_{-} \text {rating. }}$. Therefore, power flowing through each converter is quite small, only $40 \%$ of the normal power and the efficiency of DC/DC converter is too low. In this case, we need to isolate some small DC/DC converters. We suppose that in this case, the number of small DC/DC converters isolated is $m$, the new capacity of the multi-DC/DC converter can be calculated

$$
P_{\text {rated_m(n-m) }}=(n-m) P_{\text {rated_s }},
$$

and the power flowing other small DC/DC converters in this case $P_{\text {abnorm_s }}$ increases

$$
P_{\text {abnorm } \_s}=\frac{0.4 P_{p v \_r a t i n g}}{n-m}>0.4 P_{n o r m \_s} .
$$

If we designate a reasonable $m$ value, we can remain the high efficiency of converter.

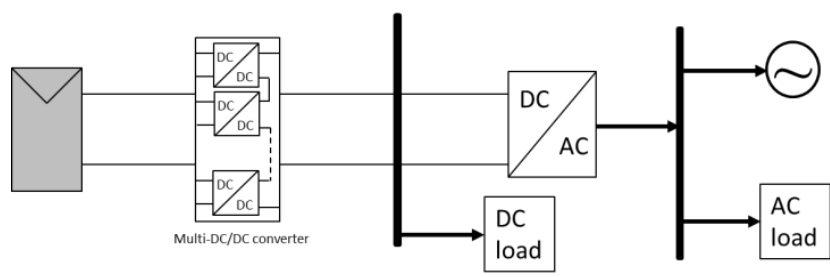

(a)

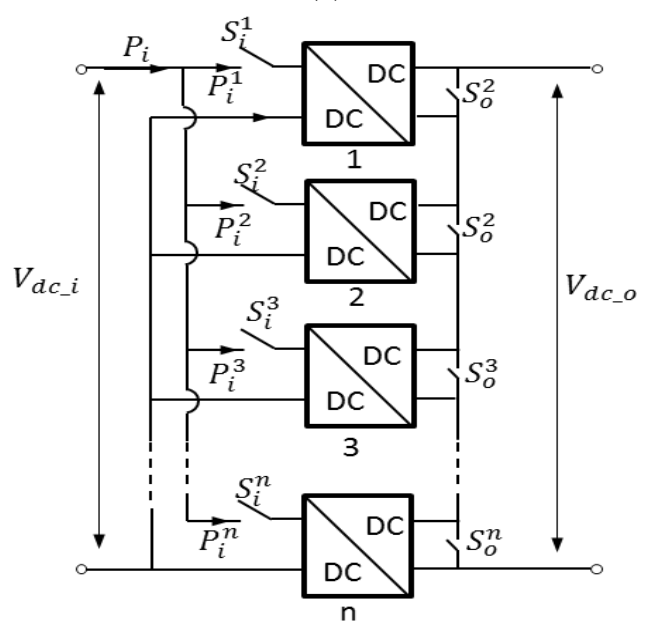

(b)

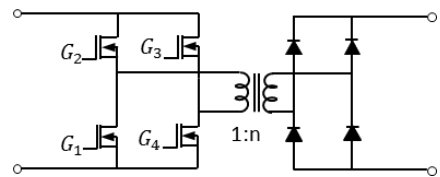

(c)

Fig.2. (a) multi-DC/DC converter in PV system, (b) structure of multi-DC/DC converter, (c) a small DC/DC converter

With the structure of the multi-DC/DC converter, let us consider the efficiency of the multi-DC/DC converter. In the case of high power output of the PV system (high irradiation), all small converters in the multi-DC/DC converter are operated and the input power of the multi-DC/DC converter is shared equally to all small converters. Hence, the power input of the multi-DC/DC converter is

$$
P_{i}=P_{i}^{1}+P_{i}^{2}+P_{i}^{3}+\cdots+P_{i}^{n},
$$

and power loss in total $\Delta P_{\text {loss }-f}$

$$
\Delta P_{\text {loss }-f}=\Delta P^{1}+\Delta P^{2}+\Delta P^{3}+\cdots+\Delta P^{n},
$$

where, $\mathrm{P}_{\mathrm{i}}^{\mathrm{i}}$ and $\Delta \mathrm{P}_{\mathrm{i}}^{\mathrm{i}}$ are active power flowing through the $\mathrm{i}^{\mathrm{th}}$ small DC/DC converter and power loss in the $\mathrm{i}^{\text {th }}$ small DC/DC converter. The power loss in the $\mathrm{i}^{\text {th }}$ small DC/DC converter is computed

$$
\Delta P_{i}^{i}=\Delta P_{R}+\Delta P_{C}+\Delta P_{C u}+\Delta P_{0}+\Delta P_{D},
$$

where $\Delta \mathrm{P}_{\mathrm{R}}, \Delta \mathrm{P}_{\mathrm{C}}$, and $\Delta \mathrm{P}_{\mathrm{D}}$ respectively represent for power loss on resistance and capacitance of Mosfet; $\Delta \mathrm{P}_{\mathrm{Cu}}$ and $\Delta \mathrm{P}_{0}$ are power loss on the winding and magnetic circuit of the 
International Journal of Engineering and Applied Sciences (IJEAS)

ISSN: 2394-3661, Volume-6, Issue-3, March 2019

transformer; $\Delta \mathrm{P}_{\mathrm{D}}$ is power loss in Diode. Hence, the efficiency of multi DC/DC converter or a large converter

$$
\eta_{f}=\frac{P_{i-f}-\Delta P_{\text {loss }-f}}{P_{i-f}}
$$

In the case of low power (low irradiation), we consider the multi-DC/DC converter with two scenarios: $\mathrm{n}$ and (n-1) small converter.

The first scenario of the multi-DC/DC converter: because $\mathrm{n}$ small DC/DC converters are operated, the efficiency is calculated.

$$
\eta_{l f}=\frac{P_{i-l}-\Delta P_{\text {loss }-f}}{P_{i-l}},
$$

where, $P_{i-l}$ is the input power in the case of low irradiance. The second scenario of the multi-DC/DC converter: we suppose that the $\mathrm{n}^{\text {th }}$ small DC/DC converter is isolated by switching off $S_{i}^{n}$ and switching on $S_{o}^{n}$. In this case, the input power of the multi-DC/DC converter is shared equally to (n-1) converters. Hence, the input power and power loss are calculated

$$
\begin{gathered}
P_{i_{-} l}=P_{i}^{1}+P_{i}^{2}+P_{i}^{3}+\cdots+P_{i}^{n-1}, \\
\Delta P_{\text {loss }-l}=\Delta P^{1}+\Delta P^{2}+\Delta P^{3}+\cdots+\Delta P^{n-1},
\end{gathered}
$$

Hence, the efficiency of the multi-DC/DC converter is

$$
\eta_{l}=\frac{P_{i-l}-\Delta P_{\text {loss }-l}}{P_{i-l}} .
$$

From (10) and (13), it is easy to see that the efficiency of DC/DC converter is improved,

$$
\eta_{l f}<\eta_{l}
$$

Hence, it is clear that the efficiency of the DC/DC converter with variable capacity is higher than that with constant capacity.

\section{VERIFICATION RESULTS}

To test the efficiency of multi-DC/DC converter, in this research, the type of solar panel used for research is PEPV-48-200. This panel has basic parameters as Table 1 and its P-V curve is shown in Fig.3.

Table 1. Parameters of solar panel PEPV-48-200

\begin{tabular}{|l|l|}
\hline Parameter & Value \\
\hline Rated power & $200 \mathrm{~W}$ \\
\hline Open circuit voltage & $30.1 \mathrm{~V}$ \\
\hline Short-circuit current & $8.84 \mathrm{~A}$ \\
\hline MPPT current & $8.37 \mathrm{~A}$ \\
\hline MPPT voltage & $23.89 \mathrm{~V}$ \\
\hline Efficiency & $15.22 \%$ \\
\hline
\end{tabular}

With this solar panel and the radiation at our laborary, by using PVsol software we can obtain the power output of PEPV-48-200W in a day as Table.2.

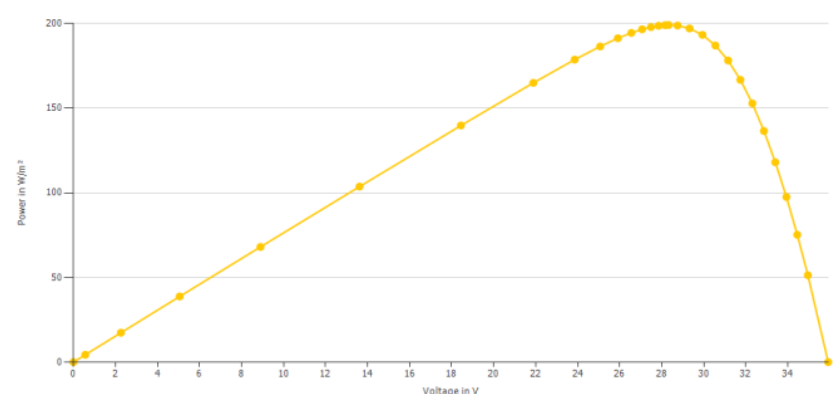

Fig 3. P-V curve of PEPV_48 $200 \mathrm{~W}$ at standard condition $\left(1000 \mathrm{~W} / \mathrm{m}^{2}, 25^{\circ} \mathrm{C}\right)$
Table 2. Power output of solar panel in a day

\begin{tabular}{|c|c|c|c|}
\hline Time & $\begin{array}{c}\text { Temperature } \\
\left({ }^{\circ} \mathrm{C}\right)\end{array}$ & $\begin{array}{c}\text { Solar } \\
\text { irradiation } \\
\left(\mathrm{Wh} / \mathrm{m}^{2}\right)\end{array}$ & $\begin{array}{c}\text { Power } \\
\text { output } \\
(\mathrm{W})\end{array}$ \\
\hline 17.02.07:00 & 26,15 & 204,27 & 30,437 \\
\hline 17.02.08:00 & 31,34 & 335,97 & 57,462 \\
\hline 17.02.09:00 & 35,68 & 446,8 & 78,642 \\
\hline $17.02 .10: 00$ & 43,97 & 702,2 & 121,93 \\
\hline $17.02 .11: 00$ & 43,95 & 648,89 & 113,01 \\
\hline $17.02 .12: 00$ & 43,96 & 633,33 & 110,12 \\
\hline $17.02 .13: 00$ & 45,97 & 697,07 & 119,74 \\
\hline $17.02 .14: 00$ & 44,08 & 619,12 & 105,47 \\
\hline $17.02 .15: 00$ & 37,41 & 385,19 & 64,304 \\
\hline $17.02 .16: 00$ & 33,01 & 276,38 & 40,458 \\
\hline $17.02 .17: 00$ & 26,66 & 28,67 & 4,002 \\
\hline
\end{tabular}

It is clear that the power output of solar panel is varied and hence if we use a DC/DC converter with constant capacity, the efficiency is too low during the low irradiation periods, take between $7 \mathrm{am}$ and $8 \mathrm{am}$ for an example. Hence, it is important to design a multi-DC/DC converter with variable capacity such that we can reduce its capacity during low irradiation periods. Here, we design a multi- DC/DC converter with its rating of $200 \mathrm{~W}$ and its structure is shown in Fig.2b. This DC/DC converter is combined from 10 small $\mathrm{DC} / \mathrm{DC}$ converters and the rating of a small DC/DC converter is $20 \mathrm{~W}$.

Here, we design the small DC/DC converter of $20 \mathrm{~W}$ as Fig.2 with components as Table 3. As a result, the multi-DC/DC converter is shown as Fig.4. It is worth to note that 10 small DC/DC converter is divided into two blocks.

Table 3. Parameters of devices in a small DC/DC converter

\begin{tabular}{|l|l|}
\hline Components & Parameter \\
\hline Diode (type 1N5822) & \multicolumn{1}{|c|}{$V_{F M}=0.39 \mathrm{~V}$} \\
\hline Transformer & $\begin{array}{l}\text { Number of winding turns: } \\
\mathrm{n}_{1}=\mathrm{n}_{2}=24 \text { turns } \\
- \text { Resistance of two windings: } \\
R_{1}=R_{2}=0.021 \Omega\end{array}$ \\
\hline $\begin{array}{l}\text { Mosfet } \\
\text { type IRF3205) }\end{array}$ & $-\mathrm{R}_{\mathrm{DS}}($ on $)=8 \mathrm{~m} \Omega$ \\
& $-\mathrm{C}_{\mathrm{iss}}=3247 \mathrm{pF}$ \\
\hline
\end{tabular}

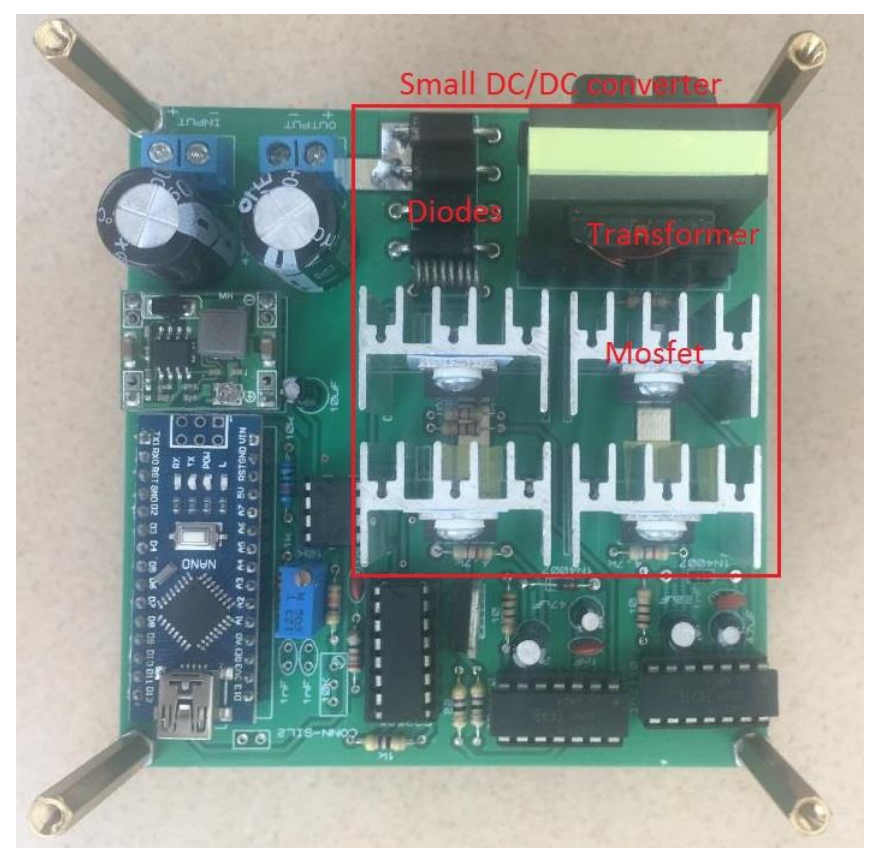

(a) 


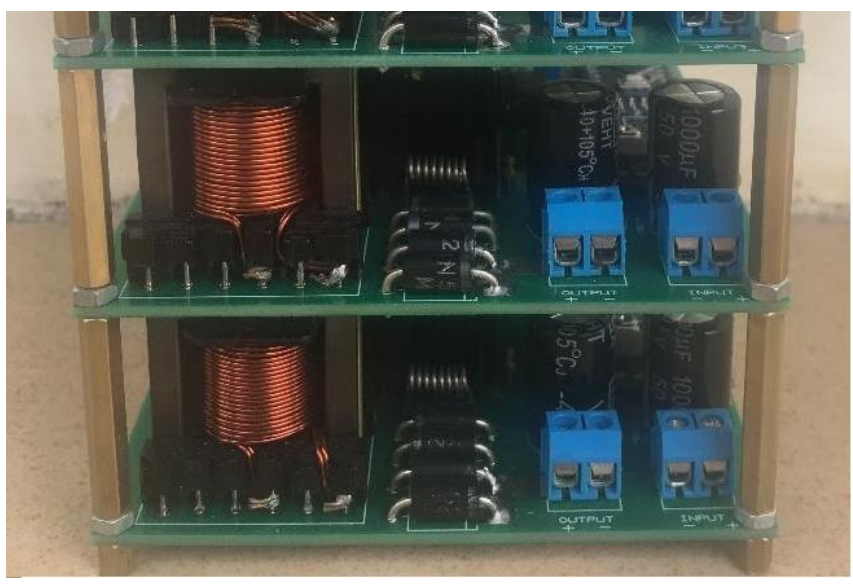

(b)

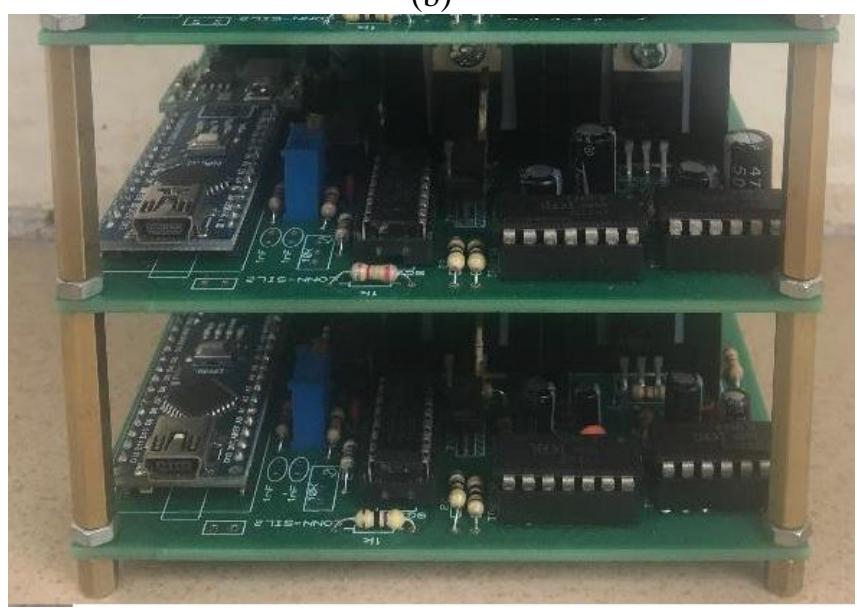

(c)

Fig.4. Real multi-DC/DC converter: (a) a small DC/DC converter, (b) front side, and (c) back side

With above small DC/DC converter, its efficiency is shown in Fig.5. We can see that its efficiency depends on current flowing it. It is easy to see that when the current is below $0.3 \mathrm{~A}$, the efficiency reduces rapidly. Hence, when a DC/DC converter applies into PV system, in low radiation period, the output power is quite small and hence, almost energy is lost in DC/DC converter. Hence, the combination of 10 small DC/DC converter to obtain a $200 \mathrm{~W}$ DC/DC converter is to be able to switch off some small DC/DC converter in the case of low output power.

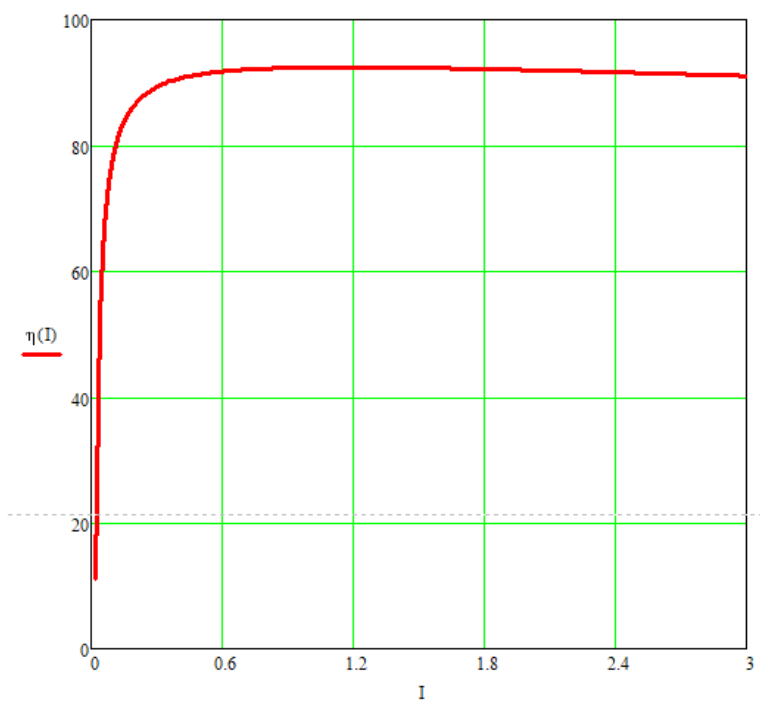

Fig.5. Efficiency of a small DC/DC converter
When we combine 20W DC/DC converters to obtain a 200W DC/DC converter, the efficiency is shown in Table 4. From this table, it is clear that in the period of $7 \mathrm{am}$ to $8 \mathrm{am}$, by switching on/off three small DC/DC converter, the efficiency of multi DC/DC converter is up to $88.2 \%$, higher than that using only one $200 \mathrm{~W}$ DC/DC converter (58.12\%). This conclusion is also seen in periods 8:00am to 9:00am and 15:00pm to $16: 00 \mathrm{pm}$. During high irradiation period, 9:00am to $15: 00 \mathrm{am}$, the multi DC/DC converter still operates the same as a DC/DC converter.

Table 4. Comparison of one DC/DC converter and multi-DC/DC converter in term of efficiency

\begin{tabular}{|c|c|c|c|c|c|c|}
\hline \multirow[b]{2}{*}{ Time } & \multirow[b]{2}{*}{$\begin{array}{c}\text { Power } \\
(\mathrm{W})\end{array}$} & \multicolumn{2}{|c|}{$\begin{array}{c}\text { One DC/DC } \\
\text { converter }\end{array}$} & \multicolumn{3}{|c|}{ Multi DC/DC converter } \\
\hline & & $\begin{array}{c}\text { Power } \\
(\%)\end{array}$ & $\eta(\%)$ & $\begin{array}{l}\text { Number } \\
\text { of small } \\
\text { DC/DC } \\
\text { converter }\end{array}$ & $\begin{array}{c}\text { Power } \\
(\%)\end{array}$ & $\eta(\%)$ \\
\hline $\begin{array}{l}17.02 . \\
07: 00\end{array}$ & 30,437 & 15,2 & 58,12 & 7 & 21,7 & 82,2 \\
\hline $\begin{array}{l}\text { 17.02. } \\
08: 00\end{array}$ & 57,462 & 28,7 & 83,46 & 8 & 35,9 & 88,12 \\
\hline $\begin{array}{l}\text { 17.02. } \\
09: 00\end{array}$ & 78,642 & 39,3 & 90,38 & 10 & 39,3 & 90,38 \\
\hline $\begin{array}{l}17.02 . \\
10: 00\end{array}$ & 121,93 & 60,9 & 91,66 & 10 & 60,9 & 91,66 \\
\hline $\begin{array}{l}17.02 . \\
11: 00 \\
\end{array}$ & 113,01 & 56,5 & 91,5 & 10 & 56,5 & 91,5 \\
\hline $\begin{array}{l}17.02 . \\
12: 00\end{array}$ & 110,12 & 55,6 & 91,43 & 10 & 55,6 & 91,43 \\
\hline $\begin{array}{l}17.02 . \\
13: 00\end{array}$ & 119,74 & 59,9 & 91,61 & 10 & 59,9 & 91,61 \\
\hline $\begin{array}{l}17.02 . \\
14: 00 \\
\end{array}$ & 105,47 & 52,7 & 91,3 & 10 & 52,7 & 91,3 \\
\hline $\begin{array}{l}17.02 . \\
15: 00\end{array}$ & 64,304 & 32,1 & 86,05 & 9 & 35,7 & 88,12 \\
\hline $\begin{array}{l}17.02 . \\
16: 00\end{array}$ & 40,458 & 20,2 & 81,11 & 7 & 28,9 & 83,61 \\
\hline $\begin{array}{l}17.02 . \\
17: 00\end{array}$ & 4,002 & 2 & 0 & 0 & 0 & 0 \\
\hline
\end{tabular}

\section{CONCLUSION}

This paper designed a multi-DC/DC converter to improve the efficiency of a PV system. This DC/DC converter is a $\mathrm{DC} / \mathrm{DC}$ converter with variable capacity to meet the variation in the output power of the photovoltaic system. The designed converter is combined from many small DC/DC converters to obtain a high enough capacity and these small DC/DC converters are possible to turn on/off so that we can change the percentage of power flowing through. By isolating some of small DC/DC converters, the power loss in a small DC/DC converter is reduced. This designed converter is evaluates via experiment shoots. The results indicate that the efficiency of proposed converter is higher than that with a conventional DC/DC converter.

\section{REFERENCES}

[1] http://www.ren21.net/wp-content/uploads/2018/06/17-8652_GSR201 8 FullReport web_-1.pdf

[2] $\bar{M}$. Arunkumar, Mr. K. Palanivelrajan, "PV FED DC-DC Converter With Two Input Boost Stages," International Journal of Engineering and Applied Sciences (IJEAS), vol.4, Iss.4, pp.24-38, April 2017. 
[3] S. Jain, V. Agarwal, "A Single-Stage Grid Connected Inverter Topology for Solar PV Systems With Maximum Power Point Tracking," IEEE Transactions on Power Electronics, vol.22, no.5, pp.1928 -1940, 2007.

[4] T. F. Wu, C. H. Chang, L. C. Lin, and C. L. Kuo, "Power Loss Comparison of Single- and Two-Stage Grid-Connected Photovoltaic Systems," IEEE Trans. Eenergy Conver., vol.26, no.2, pp.707-715, JUNE 2011.

[5] P. Riccardo, Z. Zhe, A. Michael A. E., "Analysis of DC/DC Converter Efficiency for Energy Storage System Based on Bidirectional Fuel Cells," 4th IEEE PES Innovative Smart Grid Technologies Europe (ISGT Europe), October 6-9, Copenhagen, 2013.

[6] B. Parsons, "Variability of Power from LargeScale Solar Photovoltaic Scenarios in the State of Gujarat," Technical report, https://www.nrel.gov/docs/fy14osti/60991.pdf (access on June 2018).

[7] M. S. Agamy, M. H. Todorovic, A. Elasser, R. L. Steigerwald, J. A. Sabate, S. Chi, A. J. McCann, L. Zhang, and F. Mueller, "A High Efficiency DC-DC Converter Topology Suitable for Distributed Large Commercial and Utility Scale PV Systems." 15th International Power Electronics and Motion Control Conference, EPE-PEMC 2012 ECCE Europe, Novi Sad, Serbia

[8] D. Huang, D. Gilham, W. Feng, P. Kong, Dianbo, F. C. Lee, "High Power Density High Efficiency DC/DC Converter," IEEE Energy Conversion Congress and Exposition International Conference

[9] G. Sizikov, A. Kolodny, E. G. Fridman, M. Zelikson, "Efficiency optimization of integrated DC-DC buck converters," 17th IEEE International Conference on Electronics, Circuits and Systems, pp. 1215-1218, 2010.

Trung Hieu Trinh has been a lecture at Faculty of Electrical engineering, The university of Danang-University of Science and Technology, in Vietnam since 2006. He obtained Engineering Degree and Philosophy Degree in electrical engineering from Hanoi University of Science and Technology in Vietnam in 2006 and Grenoble Institut of Technology in France in 2013, respectively. His researches are in fields of renewable energy, power electronic, and high voltage technology. Further info on his homepage: http://scv.udn.vn/tthieu 